\title{
External morphology of eyes and Nebenaugen of caridean decapods \\ - ecological and systematic considerations
}

Magnus L Johnson, Nicola C Dobson, Sammy De Grave

Most caridean decapods have compound eyes of the reflecting superposition kind and some additionally possess an accessory eye-like organ of unknown function also referred to as the nebenauge. We examined 308 caridean genera to assess the general morphology of the eye, rostrum length, eye diameter and the presence or absence and, when present, the diameter of the nebenauge. We have attempted to relate these data to ecological and taxonomic considerations. We consider there to be 6 distinct eye types based on the margin between the eyestalk and cornea. The presence of nebenaugen appears to be generally linked to an active lifestyle, as evidenced by the fact that species that have nebenaugen tend to have larger eyes and are more likely to have a distinct rostrum. We suggest that the inconsistencies in its presence/absence under both systematic and ecological lenses may indicate that when present it has various roles relating to behavioural and physiological rhythms. 
1 Nebenaugen of carideans

2 External morphology of eyes and Nebenaugen of caridean decapods - ecological and systematic

3 considerations

4 Magnus L. Johnson ${ }^{19}$, Nicola Dobson¹, Sammy De Grave ${ }^{2}$

$5{ }^{1}$ Centre for Environmental and Marine Sciences, University of Hull, Filey Road, Scarborough, YO11 3AZ

$6 \quad 2$ Oxford University of Natural History, Parks Road, Oxford, OX1 3PW

7 9 Corresponding author (m.johnson@hull.ac.uk)

\section{Abstract}

9 Most caridean decapods are thought to have compound eyes of the reflecting superposition kind and

10 some additionally possess an accessory eye-like organ of unknown function also referred to as the

11 nebenauge. We examined 308 caridean genera to assess the general morphology of the eye, rostrum

12 length, eye diameter and the presence or absence and, when present, the diameter of the nebenauge.

13 We have attempted to relate these data to ecological and taxonomic considerations. We consider there

14 to be 6 distinct eye types based on the margin between the eyestalk and cornea. The presence of

15 nebenaugen appears to be generally linked to an active lifestyle, as evidenced by the fact that species

16 that have nebenaugen tend to have larger eyes and are more likely to have a distinct rostrum. Our

17 finding that species found below $100 \mathrm{~m}$ that have larger nebenaugen may support earlier suggestions

18 that it may have a role in controlling diurnal vertical migration in pelagic species. However, we suggest

19 that the inconsistencies in its presence/absence under both systematic and ecological lenses may

20 indicate that it could have various roles relating to behavioural and physiological rhythms.

21 Accessory ocellus, doppleugen, nebenaugen, eye morphology, compound eye, dorsal spot 


\section{Introduction}

\section{Decapod eyes}

24 The laws of physics impose strict regulation on the optical and physical design of eyes and their

25 limitations are thus manifest in their physical dimensions. Larger eyes generally have greater sensitivity

26 both spatially and with regard to light intensity (Laughlin, 2001). In species such as long-bodied

27 decapods that generally have super-position compound eyes, physiological evolution would in theory

28 encourage the development of large, perfectly formed hemispheres on long eyestalks that would give

29 the bearer highly sensitive all round vision and sufficient resolution to enable accurate triangulation.

30 However, in the real world the evolution of eyes and other sensory organs is constrained by factors not

31 directly related to their function such as energy requirements, physical size, information processing

32 limitations (Laughlin, de Ruyter van Stevenwick \& Anderson, 1998; Weibel, 2000), their use as honest

33 signals (David et al., 2000) and camouflage requirements (Gaten, Shelton \& Herring, 1992; Shelton,

34 Gaten \& Herring, 1992; Johnson et al., 2000).

35 The eyes of decapods have received considerable attention with regard to their design (Cronin, 1986;

36 Meyer-Rochow, 2001; Land \& Nilsson, 2002) and their systematic importance (Fincham, 1980; Gaten,

37 1998; Porter \& Cronin, 2009). The majority of shrimp-like decapods are considered to have

38 superposition optics, thought to be an early superior development of apposition optics that when dark

39 adapted enhance the sensitivity of the eye considerably by super-imposing light from a single incident

40 source that reaches several facets onto a single rhabdom (Land \& Fernald, 1992). This is quite different

41 from an apposition eye where light from a point source will only stimulate one receptor via a single

42 facet. The superposition design must be of considerable advantage in low light conditions or at depths

43 beyond the reach of down-welling light where bioluminescence is common (Herring et al., 1990;

44 Haddock, Moline \& Case, 2010). 
Consideration of eye design in many animals has shed light on the habits of difficult to observe species such as those found in the deep-sea realm or of a crepuscular or nocturnal habit (Marshall, 1979; Herring et al., 1990). Welsh \& Chace $(1937 ; 1938)$ examined the eyes of pelagic crustaceans and noted little more than that their large size indicated that they must retain some important function. HillerAdams \& Case $(1984,1985)$ carried out some more detailed interspecific comparisons of some euphausiids and benthic decapods eyes. They noted that benthic decapods eyes get larger with depth while those of (pelagic) euphausiids become smaller. A similar observation was made of crabs by Eguchi, Dezawa \& Meyer-Rochow (1997) who found that the eyes of the deep sea crab Paralomis multispina were almost twice as large as the similar shallow water species Petrolisthes sp.

More recent investigations into the structure of eyes of species from the meso-pelagic realm, revealed tuning of eyes specific to the depths at which they were found that related well to the spectral, temporal and spatial availability of light (Shelton, Gaten \& Herring, 1992; Frank \& Widder, 1999; Johnson depths that each species inhabits. Those that live beyond the depth at which down-welling light is of no relevance to vision have a complete tapetum while those found at shallower depths have tapetal distributions that reflect the angular distribution of downwelling light they experience at the top of their depth range (Shelton, Gaten \& Herring, 1992; Johnson et al., 2000). Absences of tapetal pigment in lateral parts of the eye are thought to be linked to the fact that shrimps 'blink' during the characteristic tail flip escape response (Shelton et al., 1999). More recently close relationships have been found between eye design and habit of commensal pontonine shrimps such that it is possible to determine the lifestyle of an animal from superficial features of the eye (Dobson, De Grave \& Johnson, 2014). 
Examination of the relationship between eye size and body size in vertebrates has suggested that there is generally a logarithmic relationship between body weight and eye diameter but that the precise relationship varies depending on lifestyle (Howland, Merola \& Basarab, 2004). Leuckart's law suggests that larger, faster moving animals should have larger eyes (Laughlin, 2001). Predatory birds for example, have larger eyes than passerines (Brooke, Hanley \& Laughlin, 1999) and reef fish split into four general types (nocturnal/diurnal v grazer/predator) according to the relative sizes of their eyes and mouths (Goatley \& Bellwood, 2009). In Scaraboid beetles, data extracted from Gokan \& Meyer-Rochow (2000) suggest that absolute eye size (ommatidial length) is larger in nocturnal that diurnal species and Meyer-Rochow \& Gál (2004) found that there are structural constraints that severely limit performance in species with compound eyes of less than $0.5 \mathrm{~mm}$ diameter.

\section{The nebeneuge}

There are a bewildering array of additional light receptors in decapods - various arrangements of frontal eyes, the nebenaugen and even abdominal eyes (Elofsson, 2006). The small size of these extra 'eyes' suggests that they have restricted/limited functions and act as neural filters for specific bits of information.

The nebenauge of decapods (Figure 1) has also been referred to as doppelauge, nebenauge, a deeply pigmented ocellus, dorsal pigment spot, the pigment black spot or ocellus and accessory compound eye (Itaya, 1976; Gaten, Shelton \& Herring, 1992; Ugolini \& Borgioli, 1993). The precise arrangement and morphology of the nebeuge varies between species but it superficially resembles an apposition compound eye, closely associated with the eye proper, embedded in the eye stalk with clearly hexagonal facets and sometimes having a slightly convex cross-section. It consists of a discrete region of cornea, often positioned dorsally or posteriorly at the margin of the eye. The facets are hexagonal or irregular, even in cases where the rest of the eye has square facets. The nebenauge can vary in size 
90

91

92

93

from small, only a few facets in diameter to something that can occupy about $1 / 5$ of the diameter of the eyestalk. It is generally mentioned in taxonomic papers if it is present but appears to be assigned little in the way of systematic importance with the exception of Komai (1999) who uses its presence/absence as a diagnostic characteristic to differentiate between Pandalus and Atlantopandalus.

The internal structure of the nebenauge resembles that of the eye proper with obvious ommatidia and possessing rhabdoms a doptric layer, cornea and facets. However Itaya (1976) suggested that the angular divergence of the ommatidia of the crustacean nebenauge indicated that it was not image forming. Carlisle (1959) tentatively suggests that the nebenauge is connected to the sensory papilla xorgan in Pandalus borealis and a diagram in Carlisle \& Knowles (1959) clearly indicates a link between the nebenauge and the sinus gland in Palaemon serratus but no suggestion is made as to its possible function. They do however point out that light appears to have some impact on the release of hormones from the sinus gland in this species. Brown (1961) investigating the decapod Hippolyte varians which has no nebenaugen noted that it still exhibits a daily fluctuation in colour, even when kept in constant darkness, and integumental pigmentation is regulated by eyestalk hormones. Removal of eyestalks abolishes the daily rhythm and it is very clear that light, amongst other environmental factors has an impact on timing on reproduction and the moult cycle via a complex network of neuropeptides and the sinus gland complex (Nagaraju, 2011). Although hormones and factors deriving from the eyestalk are known to control growth, moulting, heart rate, metabolic rate, metabolism of sugars and proteins, water balance, pigment movements and reproduction (Adiyodi \& Adiyodi 1970), to date the details of the mechanisms of reproductive regulation and moult cycle progression remain hazy. Based on examinations of the eyes of mesopelagic species, Gaten et al (1992) suggest that the nebenauge is directed at the region of highest light intensity and may have a stabilising role or have something to do with the regulation of diurnal vertical migrations observed in such species. 
113 The function and systematic relevance of the nebenauge of decapods remains unclear (Gaten et al 1992,

114 Ugolini \& Borgioli, 1993) despite a long history of interest in the structure of the main eye and the

115 physiological importance of the closely associated sinus gland complex. Also there have been no

116 extensive examinations of the variation in gross eye design amongst caridean decapods and few

117 decapod systematicists recognise its potential as a useful diagnostic character.

118 Aims

119 The aims of this investigation are to examine the potential taxonomic significance and likely ecological

120 role of the nebenauge of caridean shrimps through an extensive examination of its presence absence

121 and relative size in representatives of every genera of caridean. We also assess the variation in gross

122 eye structure of decapods generally and in relation to the presence/absence of the nebenauge.

\section{Methods}

124179 adult decapods were accessed from the Oxford University Natural History Museum collection.

125 Animals had generally been preserved by immersion in $75 \%$ ethanol. One representative of every

126 genus available in the collection was used. Specimens were mounted dorsal-side up under a dissecting

127 microscope and their eyes sketched using a drawing attachment. Measurements of carapace length,

128 rostrum length, eye diameter and when present nebenauge diameter were taken using a calibrated

129 eyepiece scale. For large specimens carapace length was measured using callipers. Carapace length was

130 taken as the measurement from the posterior edge of the eye socket to the dorsal-posterior edge of the

131 carapace. Eye diameter was measured as the maximum anterio-posterior length across the eye and

132 nebenauge diameter was taken as the measurement at the widest point. Rostrum length was taken as

133 the straight line from the tip of the rostrum to the posterior-most edge of the eye socket. 
134 Although troglobitic genera were examined we found they do not have well developed eyes and so they

135 were excluded from our analysis. Where there were several genera to choose from in the collection we

136 examined the largest representative or used a species where there were numerous individuals available.

137 Details of a further 133 genera were extracted from the literature. For the most part the relevant

138 taxonomic papers were found after consultation with De Grave \& Fransen (2011). When possible,

139 carapace length, rostrum length, nebenauge presence were noted, either by direct reference to the text

140 or through observations taken from the drawings. Preliminary analysis of the dataset (see Supplemental

141 Information) indicated that measurements taken from papers were not robust enough to be anything

142 more than indicative and so were only used for presence absence of nebenaugen and rostrum length

143 classification. Analysis of a dataset with date since collection of samples indicated no effect of sample

144 age on superficial eye morphology (see Supplemental information).

145 Apportioning precise depth ranges on the basis of a few samples would not be wise so animals were

146 classified according to their deepest recorded depth distribution into freshwater, coastal (0-99 m), shelf

$147(100-300 \mathrm{~m})$ and deep $(>300 \mathrm{~m})$ based on available information from the literature. Freshwater

148 specimens were not classified by depth because of the wider range of optical properties of lentic and

149 lotic environments. Animals were also categorised by habitat (temperate, tropical, deepsea) and as

150 either commensal or free living.

\section{Analysis}

152 All analyses were carried out using the statistical package R (Ihaka \& Gentleman, 1996). Where

153 necessary and possible data were normalised via log transformations so that parametric techniques

154 could be applied. Normality was assessed using the Shapiro-Wilks test. 


\section{Results}

\section{Morphological variations}

157 We found that eyes could generally be classed into 6 major types according to the shape of the margin

158 between the eyestalk and the cornea (Figure 2), general shape and further classified by the presence or 159 absence of the nebenauge.

160 The distribution of eye types among families was not random $\left(X^{2}=285.5\right.$, d.f. $\left.=11,308, p<0.0001\right)$ and

161 neither was the distribution of nebenaugen among them (See Table 1). Although present in 14 families, 162 the most basic eye design (Type 1) which consists of a tube shaped eyestalk and a simple hemispherical 163 eye was the most common because it was favoured by the most speciose sub-family, the Pontoniinae.

164 Fifteen families possessed the next most common, Type 2 eyes which is the only classification that has 165 more species with nebenaugen than without. Type 6, which generally consisted of reduced eyes, was 166 the only classification where none of the examples examined possessed a nebenauge.

\section{Nebenaugen}

168 We examined the eyes of 308 non-troglobitic genera from 26 families (Table 1 ) and found that 88 169 possessed a discernible nebenauge (28.6\%). We found that the distribution of nebenaugen across 170 caridean families, where we sampled more than the minimum of 5 genera, deviates from a 50:50

171 distribution overall ( $p<0.001$, Table 1). There appear to be some links between its presence/absence and 172 systematics with non-random differences in the prevalence of nebenaugen. The distribution of 173 nebenaugen amongst genera by family could be split into those where genera had about a $25-50 \%$ 174 chance of having one (Hippolytidae, Oplophoridae and Pandalidae), those where they occurred 175 infrequently (Pontoniinae and Atyidae) and those where none were found for any species (Alpheidae 176 and Crangonidae). The only family where significantly more genera were found to have nebenaugen 177 than not were the Palaemonidae. There are no families where all genera possess a nebenauge. Analysis 
of the data for the 7 families where there were more than 10 genera sampled suggested that the pattern was not random $\left(X^{2}=53.68\right.$, d.f. $\left.=6,245, p<0.001\right)$. For families where fewer than 10 animals were sampled the proportion of those in possession does not deviate significantly from 50:50 (i.e. $p>0.05)$ with the exception of the Pasiphaeidae $(n=7)$. Given the small numbers in these families however it would perhaps be unwise to draw any conclusions.

A chi-squared test of distribution of nebenaugen between commensal and free-living genera indicated that there was no deviation from independence $\left(X^{2}=1.0712\right.$, d.f. $\left.=1,308, p=0.399\right)$. No deviation from independence was noted for the distribution between freshwater and marine genera $\left(X^{2}=0.0136\right.$, d.f. $=$ $1,303, p=0.9073)$ or by depth class $\left(X^{2}=1.012\right.$, d.f. $\left.=3, p=0.799\right)$. Neither was there any a significant pattern noted in relation to the light regime shrimps experienced; a similar prevalence of nebenaugen was noted for deep, temperate and tropical-living decapods $\left(X^{2}=1.297\right.$, d.f. $\left.=2, p=0.523\right)$. However, the distribution of nebenaugen among shrimps depending on the size class of their rostrum (Figure 3) appears to show a pattern $\left(X^{2}=32.583\right.$, d.f. $\left.=1,256, p<0.001\right)$. There is a positive association between the likelihood of a shrimp with a particular eye type having a medium or long rostrum and it having a nebenauge (Kendall rank correlation, tau=0.867, d.f. $=1,5, p=0.01667$ ).

Allometry of the eye and nebenauge

Neither carapace length nor eye diameter were normally distributed and so were logged. There is a significant relationship between log carapace length $(C L)$ and log eye diameter $\left(p<0.0001, r^{2}=0.656\right.$, d.f. $=1,168)$. A least squares regression gave the relationship log eye diameter $=0.723 \log C L-1.315$

(Figure 4). Overall, animals with nebenaugen tended to have larger eyes both in terms of absolute dimension $(F=6.449$, d. $f=168, p=0.012)$ and relative to carapace length $(F=5.997, d . f .=168 p=0.0154)$ than those that did not. Although no significant difference in relative eye diameter could be 
among the five families where there were sufficient species with and without nebenaugen (Figure 5).

Also a comparison of relative eye diameter among rostrum size classes (Figure 6) revealed that animals $\mathrm{p}<0.0001)$.

When the size of the eye relative to carapace length was examined according to broad habitat and depth classifications (Figure 7) there was no variation for species that had a nebenauge (KW test, $\left.\mathrm{X}^{2}=0.589, \mathrm{p}=0.899\right)$ but for those lacking nebenaugen there was significant variation ( $\mathrm{KW}$ test, $\mathrm{X}^{2}=$ $13.817, p<0.005)$. This was caused by the significant difference in relative eye diameter between deep living species depending on the presence/absence of the nebenauge (Wilcox test; $W=58, p<0.005$ ). that there was a significant difference by marine habitat classification (Kruskal-Wallis, $X^{2}=9.5025, \mathrm{df}=3$, $p$-value $=0.0233)$ with freshwater animals generally having much reduced nebenaugen (Figure 8 ). The nebenaugen angle in species that are known to undergo diurnal vertical migration (i.e. Oplophorids, $W=65, p<0.001)$

\section{Discussion}

We have demonstrated that in caridean decapods eye size has an approximately log-log relationship

219 with carapace length (Figure 4). We have also found that there is a general trend for animals that have nebenaugen to have larger eyes relative to their carapace length. Larger eyes can either deliver greater

221 sensitivity through a larger aperture and larger rhabdoms or offer an opportunity for better resolution 222 through reduced interommatidial angles. 
223 Although the link may be considered tenuous given the numbers of pelagic decapods that have small

224 rostra (Sarda, Company \& Costa, 2005), we have used the presence of a large rostrum, which would be a 225 physical hindrance to an endocommensal or infaunal habit, as an indicator that these species are likely

226 to be free living and active swimmers. Our data suggest that animals that have a long rostrum relative

227 to carapace length tend to have larger eyes and are more likely to have nebenaugen (Figures $3 \& 6$ ).

228 These findings concur with a previous study focussed on symbiotic pontoniine decapods (Dobson, De

229 Grave \& Johnson, 2014) where it was found that endosymbiotic species had smaller eyes and were less

230 likely to have nebeugen. The costs and benefits of having large eyes will be a function of various

231 ecological parameters such as temporal activity patterns, mode of prey capture and the availability of

232 visually relevant light (Talarico et al., 2007; Rutowski, Gislén \& Warrant, 2009). Offset against any

233 potential advantages, the rapid rise of metabolic cost with increasing size in compound eyes is likely to

234 encourage the evolution of the smallest eye appropriate to the needs of the animal (Weibel, 2000;

235 Laughlin, 2001).

236 In marine species the likely relationships between habitat, lifestyle, gross eye morphology and eye size

237 will be further complicated by consideration of habitat depth. Depth has been shown to have a strong

238 impact on the morphology and function of decapod eyes (Johnson et al., 2000). Animals found in

239 shallower water tend to have "faster" eyes with a greater capacity for light adaptation than those from

240 the deep sea (Johnson, Shelton \& Gaten 2000; Johnson 1998). With regard to eye diameter, our finding

241 that for species without nebeaugen relative eye size is smallest in deepsea species is contrary to that of

242 Hiller-Adams \& Case (1985) for benthic decapods but matches that of Hiller-Adams \& Case (1984) for

243 euphausiids. This may reflect the fact that many smaller decapods have a demersal rather than truly

244 reptant or benthic lifestyle, more similar to euphausiids than lobsters. The general pattern in these

245 decapods appears to be that at greater depths eyes become less important is perhaps a reflection of

246 some suggestions that the relative importance of chemosensitivity is greater in deep-sea species 
247 (Fuzessery \& Childress, 1975; Marshall, 1979). The decrease in eye size may correlate with observations

248 by neuroanatomists of changes in brain architecture in some caridean decapods that may indicate a

249 reduction in visual capability in species with small eyes (Sandeman et al. 1993). Bathypelagic fish have

250 small eyes with large pupils which Warrant (2000) suggests is a reflection of the changing nature of the

251 visual scene with depth - animals at depths beyond daylight penetration are adapted to see point

252 sources of light rather than broad and detailed visual scenes.

253 For species that have a nebenauge our data suggest that there is no trend in eye size with depth-related

254 habitat classification (Figure 7) but that for these species the organ is as large or larger in species

255 generally found below $100 \mathrm{~m}$ (Figure 8). This new finding suggests that the organ is an important

256 adaptation for deep sea species, many of which in our study are regarded as pelagic. Although food

257 availability is implicated in vertical migrations of some species such as Euphausia superba (Tarling \&

258 Johnson, 2006) it is generally accepted that light triggers diurnal vertical migration of planktonic

259 organisms (either directly or indirectly) in temperate and tropical regions (Aguzzi \& Company, 2010;

260 Ochoa et al., 2013). The large size of the nebenaugen when it is present in species found below $100 \mathrm{~m}$

261 or that are mesopelagic vertical migrators may lend further credence to the suggestion by Gaten,

262 Shelton \& Herring (1992) that the organ functions as a photometer for monitoring downwelling light and

263 is linked to the control of diurnal vertical migration.

264 We have found that the prevalence of nebenaugen within families is not random. Of the families that

265 lack nebeneugen the Alpheids are burrow/shelter dwellers, the Atyidae are mostly freshwater, the

266 Crangonidae are highly benthic and burrowing (Bauer, 2004) and the Pasipheidae have smaller eyes

267 relative to their carapace length than all families except the Ogyridae. Of the families where

268 nebenaugen are common the Oplophoridae are mesopelagic, Hippolytidae are diverse epibenthic

269 marine perchers, Palaemoninae are a diverse sub-family that has repeatedly invaded freshwater, 
Pandalidae are generally medium to large epibenthic schooling species and Pontoniinae are exclusively

271 marine/brackish water, hugely diverse and often symbiotic (Bergstrom, 2000; Bauer, 2004; Ashelby et

272 al., 2012). These factors lend credence to the idea that the presence and absence of the nebenauge in

273 carideans is loosely tied to lifestyle; active epibenthic or pelagic species are more likely to have them

274 than burrowing mostly benthic species. However the systematic or indeed ecological pattern of

275 occurrence is not absolute.

276 We have concluded that there are six recognisable classifications for caridean decapod eyes based on

277 the shape of the eye and the boundary between the cornea and eyestalk and noted that the distribution

278 of nebeaugen is also not random among eye types. Animals with reduced eyes, such as the Alpheidae

279 never have a nebenauge. For 4 out of the 6 eye types examined, the prevalence of the nebenauge is

280 less frequent than would be expected by chance and for the other two families the distribution does not

281 differ significantly from 50:50. Given the current uncertainty as to how the nebenauge is connected to

282 the x-organ/sinus gland ( Carlisle 1959) there is a possibility that the distinctions we have made between

283 eye types may be cosmetic as much as functional. If the nebenauge has an important function the

284 obvious questions are, 1) What does it do, and 2) How is its function covered in species that do not have

285 one? Given the inconsistencies in taxonomic and ecological distributions of the nebenauge it seems

286 likely that there is no single simple answer - it may have different functions in different groups.

287 However, given the plasticity of systems determining endogenous rhythms (Yerushalmi \& Green, 2009)

288 and the possible links the nebenauge has with the sinus gland complex this area merits further

289 investigation.

\section{Conclusion}

291 We conclude that, although as with previous investigations there appears to be no clear taxonomic

292 pattern in its distribution by family and although we cannot ascribe a function to the nebenauge of 
caridean decapods, its presence appears to be linked to lifestyle. It is more frequently present as eye size of a species increases and shows an association with relative rostrum length. If size is an indication of ecological importance then the fact that it is larger in species found below $100 \mathrm{~m}$ suggests that it has a particularly important role in some deep-water species. With regard to the superficial morphology of caridean eyes, we have found a log-log relationship between carapace length and eye diameter and suggest that there are 6 identifiable eye morphotypes based on general morphology and the margin between eyestalk and cornea.

\section{Acknowledgements}

We gratefully acknowledge the detailed comments of B Schoenemann and VB Meyer-Rochow which markedly improved the manuscript.

Adiyodi KG, Adiyodi RG. 1970. Endocrine control of reproduction in decapod Crustacea. Biological reviews of the Cambridge Philosophical Society 45:121-65.

Aguzzi J, Company JB. 2010. Chronobiology of Deep-Water Decapod Crustaceans on Continental Margins. Advances in Marine Biology 58:155-225.

Ashelby CW, Page TJ, De Grave S, Hughes JM, Johnson ML. 2012. Regional scale speciation reveals multiple invasions of freshwater in Palaemoninae (Decapoda). Zoologica Scripta 41:293-306.

Bauer R. 2004. Remarkable Shrimps. University of Oklahoma Press.

Bergstrom B. 2000. The biology of Pandalus. Advances in Marine Biology 128:1-245.

Brooke M de L, Hanley S, Laughlin SB. 1999. The scaling of eye size with body mass in birds. Proceeding of the Royal Society London B 266:405-412.

Brown FA. 1961. Physiological Rhythms. In: Waterman TH ed. The Physiology of Crustacea: Sense organs, integration and behavior. New York: Academic Press, 401-430.

Carlisle DB. 1959. On the sexual biology of Pandalus borealis (Crustacea Decapoda). I. Histology of incretory elements. Journal of the Marine Biological Association 38:381-394. 
Carlisle DB, Knowles F. 1959. Endocrine control in crustaceans. Cambridge: Cambridge University Press.

Cronin TW. 1986. Optical design and evolutionary adaptation in crustacean compound eyes. Journal of Crustacean Biology 6:1-23.

David P, Bjorksten T, Fowler K, Pomiankowski A. 2000. Condition-dependent signalling of genetic variation in stalk-eyed ${ }^{-}$ies. Nature 406:186-188.

De Grave S, Fransen C. 2011. Carideorum Catalogus: The recent species of the Dendrobrachiate, Stenopodidean, Procarididean and Caridean shrimps (Crustacea: Decapoda). Zool. Med. Leiden 85:195-588.

Dobson NC, De Grave S, Johnson ML. 2014. Linking eye design with host symbiont relationships in pontoniine shrimps (crustacea, decapoda, palaemonidae). PLOS ONE 9:1-12.

Dobson N, Johnson M, DeGrave S. 2015. Comparative study on the eye morphology of Pontoniine shrimps (Crustacea, Decapoda, Palaemonidae); the effects of habitat demands. in prep.

Eguchi E, Dezawa M, Meyer-Rochow VB. 1997. Compound eye fine structure in Paralomis multispina Benedict, an anomuran half-crab from 1200 m depth (Crustacea; Decapoda; Anomura). Biological Bulletin 192:300-308.

Elofsson R. 2006. The frontal eyes of crustaceans. Arthropod structure \& development 35:275-91.

Fincham AA. 1980. Eyes and classification of malacostracan crustaceans. Nature 287:729-731.

Frank TM, Widder EA. 1999. Comparative study of the spectral sensitivities of mesopelagic crustaceans. J. Comp. Physiol. A 185:255-265.

Fuzessery Z, Childress J. 1975. Comparative chemosensitivity to amino acids and their role in the feeding activity of bathypelagic and littoral crustaceans. The Biological Bulletin 149:522-538.

Gaten E. 1998. Optics and phylogeny: is there an insight? The evolution of superposition eyes in the Decapoda (Crustacea). Contributions to Zoology 67:223-236.

Gaten E, Shelton PMJ, Herring PJ. 1992. Regional morphological variations in the compound eyes of certain mesopelagic shrimps in relation to their habitat. Journal of the Marine Biological Association 72:61-75.

Goatley CHR, Bellwood DR. 2009. Morphological structure in a reef fish assemblage. Coral Reefs 28:449457.

Gokan N, Meyer-Rochow VB. 2000. Morphological comparisons of compound eyes in Scarabaeoidea (Coleoptera) related to beetles' daily activity maxima and phylogenetic position. Jour. Agri. Sci. 45:15-61.

Haddock SHD, Moline MA, Case JF. 2010. Bioluminescence in the Sea. Annual Reviews in Marine Science. 
Herring P, Campbell A, Whitfield M, Maddock L. 1990. Light and Life in the Sea. Cambridge: Cambridge University Press.

Hiller-Adams P, Case JF. 1984. Optical parameters of euphaisiid eyes as a function of habitat depth. J. Comp. Physiol. 154:307-318.

Hiller-Adams P, Case JF. 1985. Optical parameters of the eyes of some benthic decapods as a function of habitat depth (Crustacea, Decapoda). Zoomorphology 105:108-113.

Howland HC, Merola S, Basarab JR. 2004. The allometry and scaling of the size of vertebrate eyes. Vision Res. 44:2043-2065.

Ihaka R, Gentleman R. 1996. R: A Language for Data Analysis and Graphics. Journal of Computational and Graphical Statistics 5:299-314.

Itaya SK. 1976. Light and dark adaptational changes in the accessory eye of the shrimp Palaemonetes. Tissue and Cell 8:583-590.

Johnson ML. 1998. Aspects of vision in mesopelagic decapods. University of Leicester.

Johnson ML, Shelton PMJ, Gaten E, Herring P. 2000. Relationship of dorsoventral eyeshine distributions to habitat depth and animal size in mesopelagic decapods. Biological Bulletin 199:6-13.

Johnson ML, Gaten E, Shelton PMJ. 2002. Spectral sensitivities of five marine decapod crustaceans and a review of spectral sensitivity variation in relation to habitat. J. Mar Biol. Ass. UK 82:835-842.

Johnson ML, Shelton PMJ, Gaten E. 2000. Temporal resolution in the eyes of marine decapods from coastal and deep-sea habitats. Marine Biology 136:243-248.

Komai T. 1999. A revision of the genus Pandalus (Crustacea: Decapoda: Caridea: Pandalidae). Journal of Natural History 33:1265-1372.

Land MF, Fernald RD. 1992. The evolution of eyes. Annual Review of Neuroscience 15:1-29.

Land MF, Nilsson D-EE. 2002. Animal Eyes. Oxford: Oxford University Press.

Laughlin SB. 2001. The metabolic cost of information - a fundamental factor in visual ecology. In: Barth F, Schmid A eds. Ecology of Sensing. Berlin: Springer, 169-185.

Laughlin SB, de Ruyter van Stevenwick RR, Anderson JC. 1998. The metabolic cost of neural information. Nature Neuroscience 1:36-41.

Marshall NB. 1979. Developments in Deep-Sea Biology. Poole: Blanford.

Meyer-Rochow VB. 2001. The crustacean eye: dark/light adaptation, polarization sensitivity, flicker fusion frequency, and photoreceptor damage. Zoological science 18:1175-1197. 
Meyer-Rochow VB, Gál J. 2004. Dimensional limits for arthropod eyes with superposition optics. Vision research 44:2213-23.

Mylinski TJ, Frank TM, Widder EA. 2005. Correlation between photosensitivity and downwelling irradiance in mesopelagic crustaceans. Marine Biology 147:619-629.

Nagaraju GPC. 2011. Reproductive regulators in decapod crustaceans: an overview. The Journal of experimental biology 214:3-16.

Ochoa J, Maske H, Sheinbaum J, Candela J. 2013. Diel and lunar cycles of vertical migration extending to below $1000 \mathrm{~m}$ in the ocean and the vertical connectivity of depth-tiered populations. Limnology and Oceanography 58:1207-1214.

Porter ML, Cronin TW. 2009. A shrimp eye view of evolution: How useful are visual characters in decapod phylogenetics? In: Martin JW, Cronin TW eds. Decapod Crustacean Phylogenetics.

Rutowski RL, Gislén L, Warrant EJ. 2009. Visual acuity and sensitivity increase allometrically with body size in butterflies. Arthropod Structure and Development 38:91-100.

Sandeman DC, Scholtz G, Sandeman RE. 1993. Brain Evolution in Decapod Crustacea. Journal of Experimental Zoology 265:112-133.

Sarda F, Company J, Costa C. 2005. A morphological approach for relating decapod crustacean cephalothorax shape with distribution in the water column. Marine Biology 147:611-618.

Shelton PMJ, Gaten E, Johnson ML, Herring PJ. 1999. The "eye-blink" response of meso-pelagic Natantia, eyeshine patterns and escape reaction. In: Klein JCVV, Schram FR eds. The Biodiversity Crisis and Crustacea. Proceedings of the Fourth International Crustacean Congress, Amsterdam, The Netherlands, July 20-24, 1998. Rotterdam: A.A. Balkema, 253-257. (https://www.youtube.com/watch?v=s_36AQAzgdg)

Shelton PMJ, Gaten E, Herring P. 1992. Adaptations of tapeta in the eyes of mesopleagic decapod shrimps to match the oceanic irradiance distribution. Journal of the Marine Biological Association 72:77-88.

Talarico F, Romeo M, Massolo a., Brandmayr P, Zetto T. 2007. Morphometry and eye morphology in three species of Carabus (Coleoptera: Carabidae) in relation to habitat demands. Journal of Zoological Systematics and Evolutionary Research 45:33-38.

Tarling GA, Johnson ML. 2006. Satiation gives that sinking feeling. Current Biology 16:R83-R84.

Ugolini A, Borgioli E. 1993. On the "accessory eye" of shrimps (Decapoda, Natantia). Crustaceana 65:112-115.

Warrant E. 2000. The eyes of deep-sea fishes and the changing nature of visual scenes with depth. Philosophical transactions of the Royal Society of London. Series B, Biological sciences 355:11551159. 
414 Weibel ER. 2000. Symmorphosis: on form and function in shaping life. Cambridge: Harvard University 415 Press.

416 Welsh JH, Chace FA. 1938. Eyes of deep sea crustaceans. II. Sergestidae. Biological Bulletin 74:364-375.

417 Welsh JH, Chace F. 1937. Eyes of Deep Sea Crustaceans . I . Acanthephyridæ. Biological Bulletin 72:57$418 \quad 74$.

419 Wong JM, Perez-Moreno JL., Chan T, Frank T, Felder DL, Bracken-Grissom HD. 2015. Phylogenetic and 420 transcriptomic analyses reveal the evolution of bioluminescence and vision in marine deep-sea 421 shrimp (Decapoda: Oplophoridae). Evolution. 83:278-292.

422 Yerushalmi S, Green RM. 2009. Evidence for the adaptive significance of circadian rhythms. Ecology $423 \quad$ Letters 12:970-981. 


\section{1}

Electron micrographs

[p] Figure 1: Electron micrographs of the dorsal region of

Caridean eyes. a-b) Cuapetes elegans,

c-d) Cinetorhynchus Henderson. Note

the presence of tegumental scales on this species (Degrave and Wood, 2011) e-f)

Gnathophyllum americanum. Note the peaked cornea which is a typical

feature of this genus. [p]

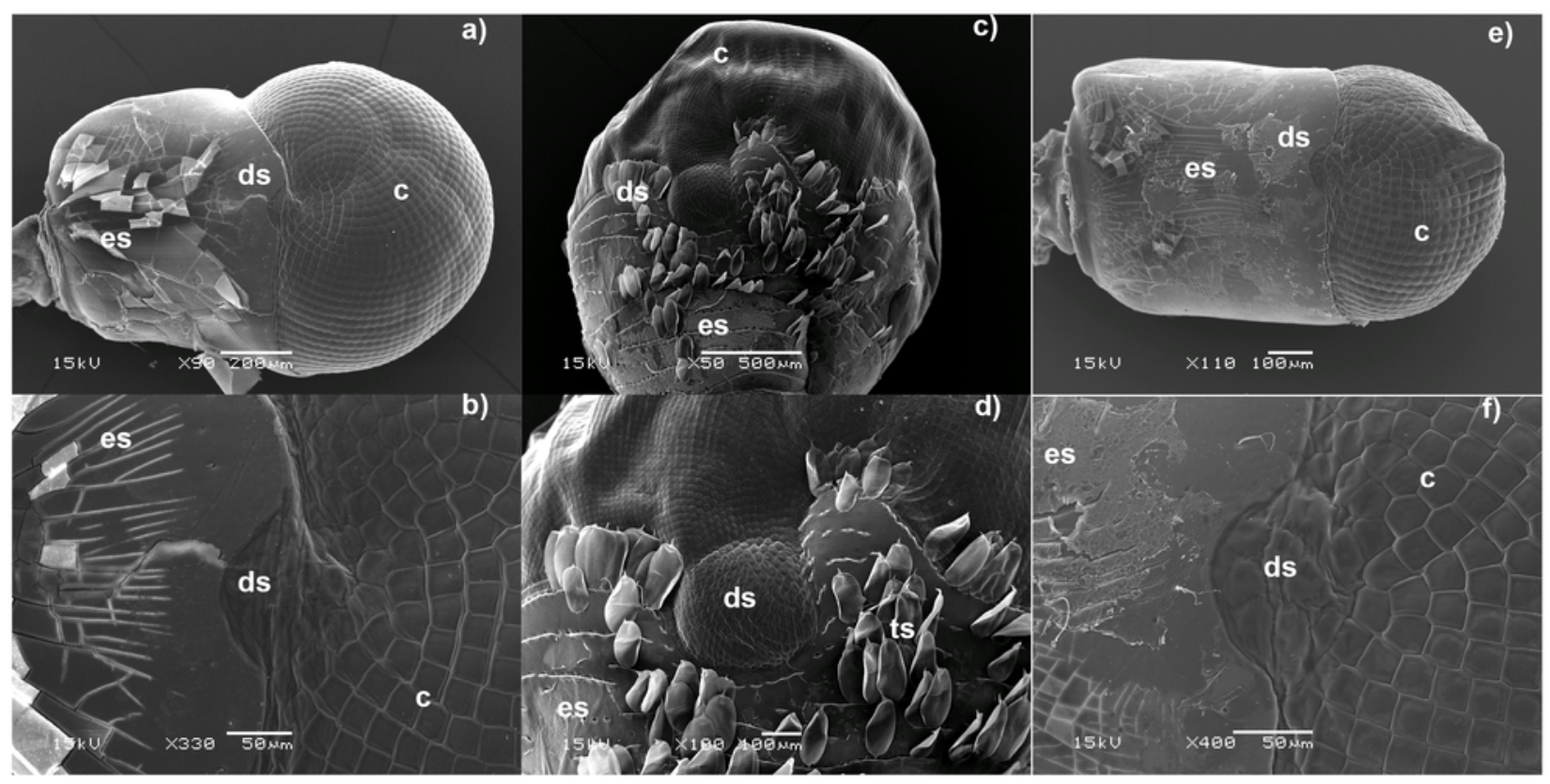


2

Morphological classifications of eyes

[p] Figure 2: Morphological classifications of eyes based on the corneal margin when viewed dorsally. Classification 6 (not illustrated) includes all reduced and vestigial eyes lacking superposition or apposition structure. [p] 


\begin{tabular}{|l|l|}
\hline & $\begin{array}{l}\text { Classification 1 - Straight } \\
\text { Margin of eye is straight and about per- } \\
\text { pendicular to eyestalk major axis. The } \\
\text { eyestalk is about the same width, or not } \\
\text { much narrower than the eye. }\end{array}$ \\
\hline Mimocaris & $\begin{array}{l}\text { Classification 2 - Sinuous } \\
\text { Margin of eye has a small, often 'S } \\
\text { shaped wiggle. The nebenauge, when } \\
\text { present, is incorporated into the area } \\
\text { where the eyestalk margin deviates from } \\
\text { straight. }\end{array}$ \\
\hline antiguensis (1)
\end{tabular}


Figure 3 (on next page)

Nebenaugen proportions

[p] Figure 3: Proportion of Caridean decapods that have a nebenauge

in relation to the relative length of their rostra. Rostrum size is relative to the carapace length. [p] 


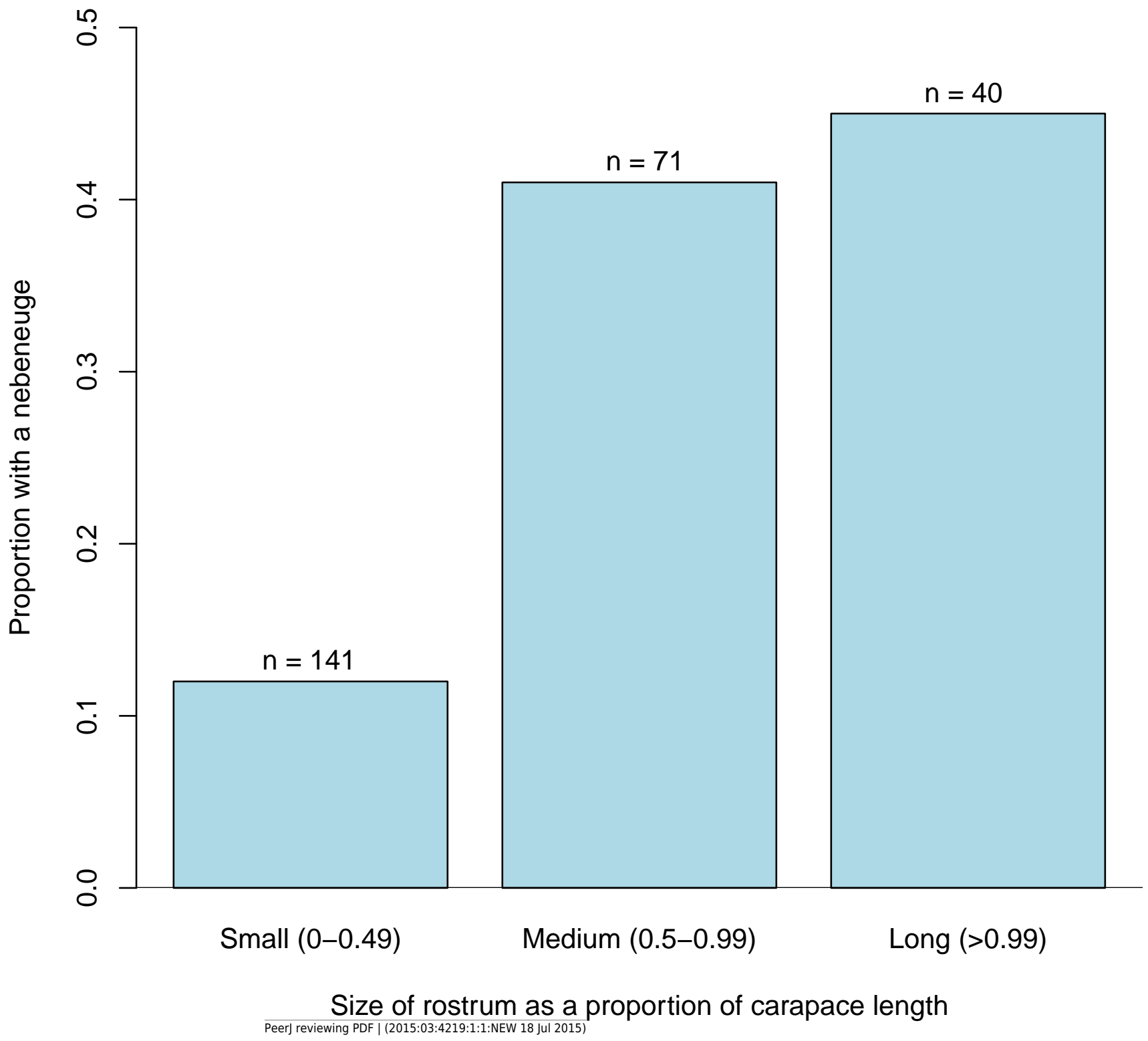


Figure 4(on next page)

Carapace length $v$ eye diameter

[p] Figure 4: The relationship between log carapace length and log

eye diameter in caridean decapods. [p] 


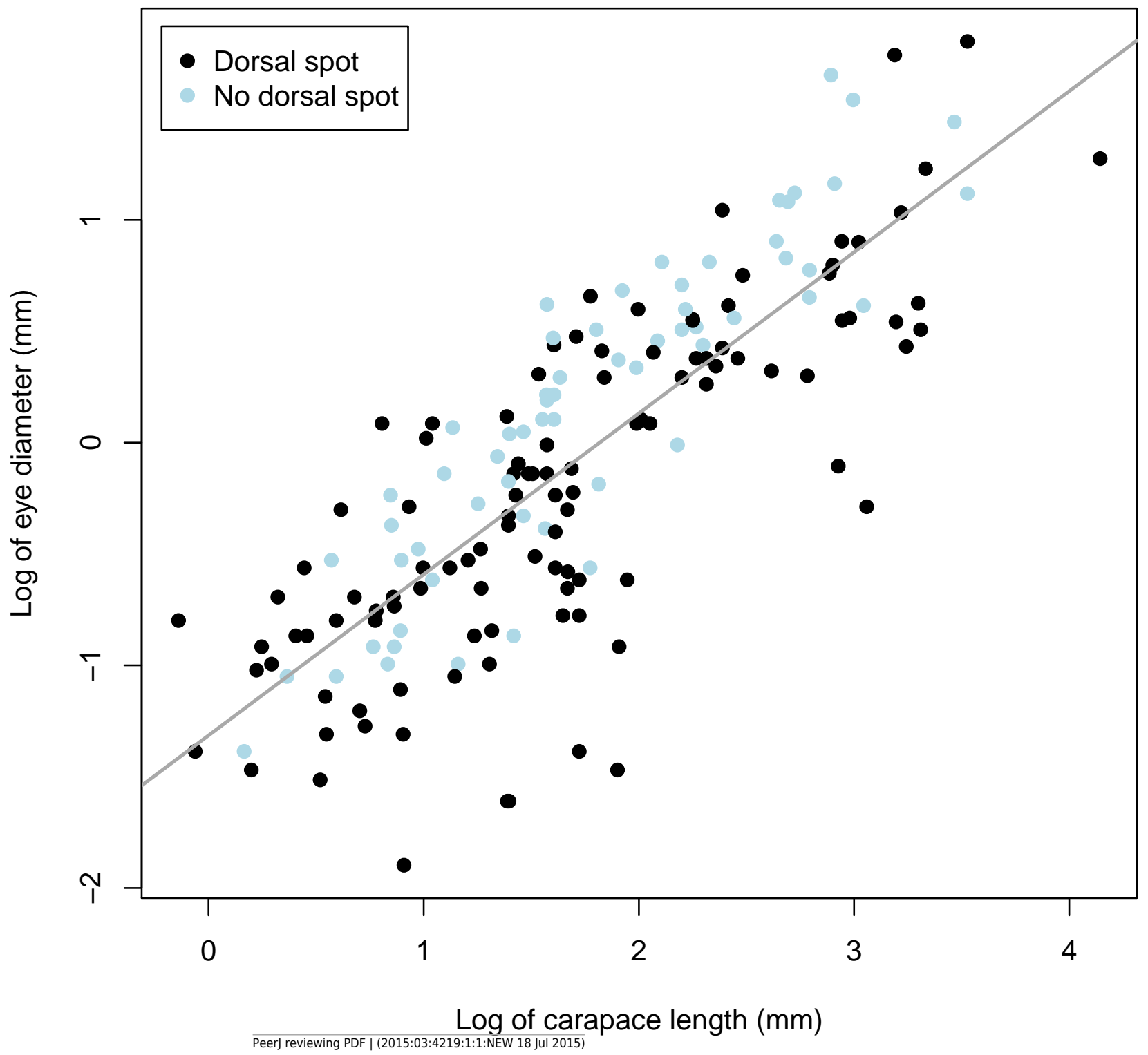


Figure 5 (on next page)

Relative eye diameter and nebenaugen

[p] Figure 5: Relative eye diameter in relation to the presence or absence of a nebenauge. Animals with nebenaugen generally have larger eyes relative to carapace length. [p] 
Figure $\mathbf{6}$ (on next page)

Eye diameter and rostrum length

[p] Figure 6: Comparison of relative eye diameter between

animals that have a rostrum less than or greater than the length of their carapace. [p] 
Figure 7 (on next page)

Eye diameter and depth

[p] Figure 7: Relative eye diameters of animals from freshwater and three marine depth ranges depending on presence/absence of nebeaugen. Depths are Coastal 0-100 m, Shelf 101-300 m, Deep, > 300 m. [p] 


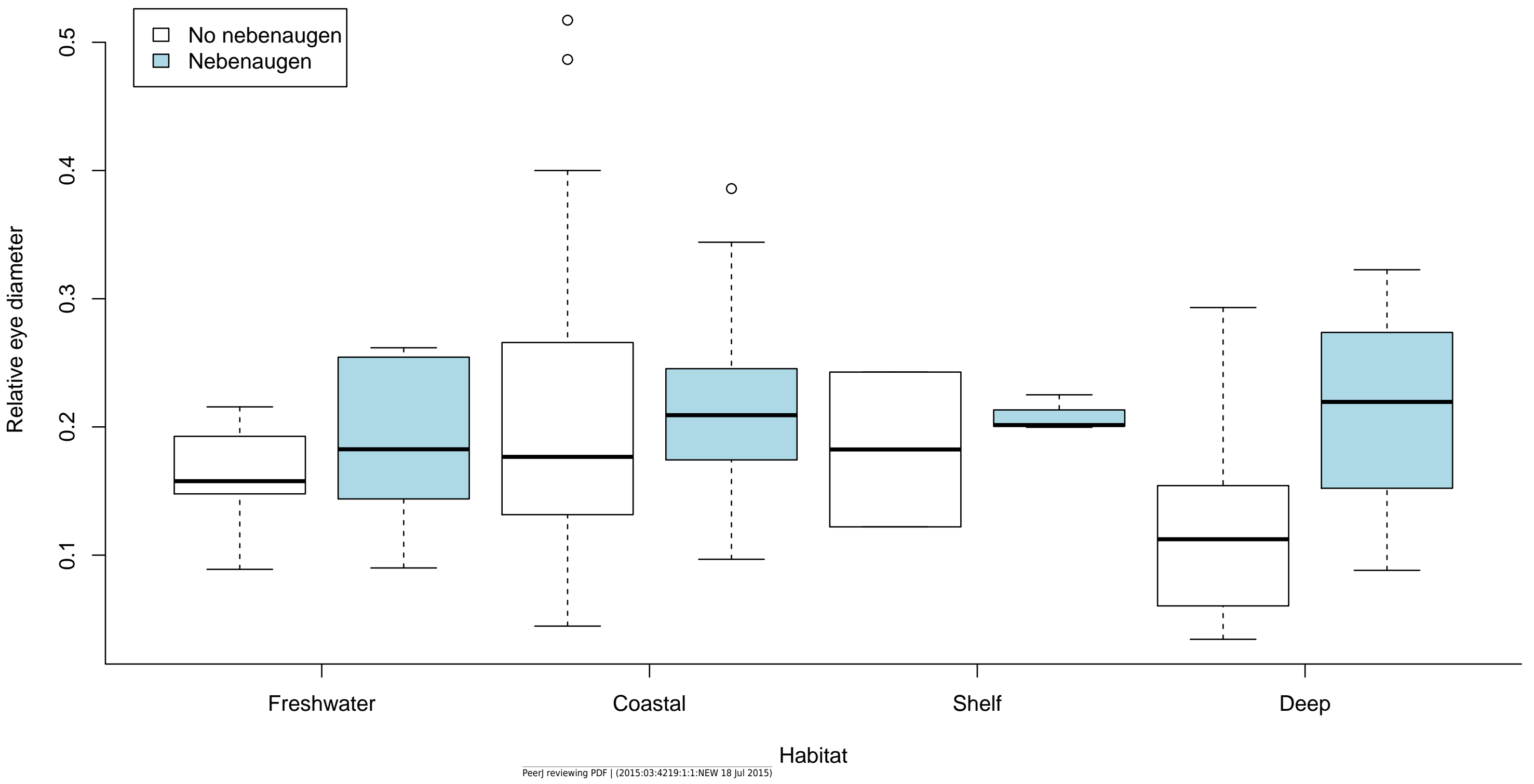


Figure 8 (on next page)

Nebenaugen angle and habitat

[p] Figure 8: Comparison of the angle that nebenaugen occupy by habitat (angle calculated as [i] ). Depth ranges are Coastal, 0-100 m; Shelf, 101-300 m; Deep, > 300m. [p] 
O

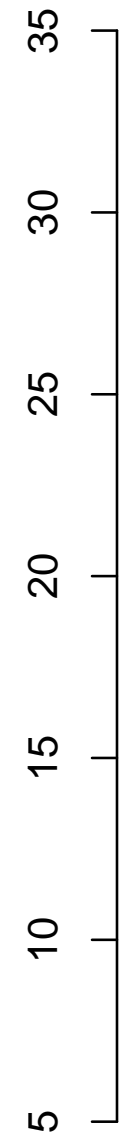
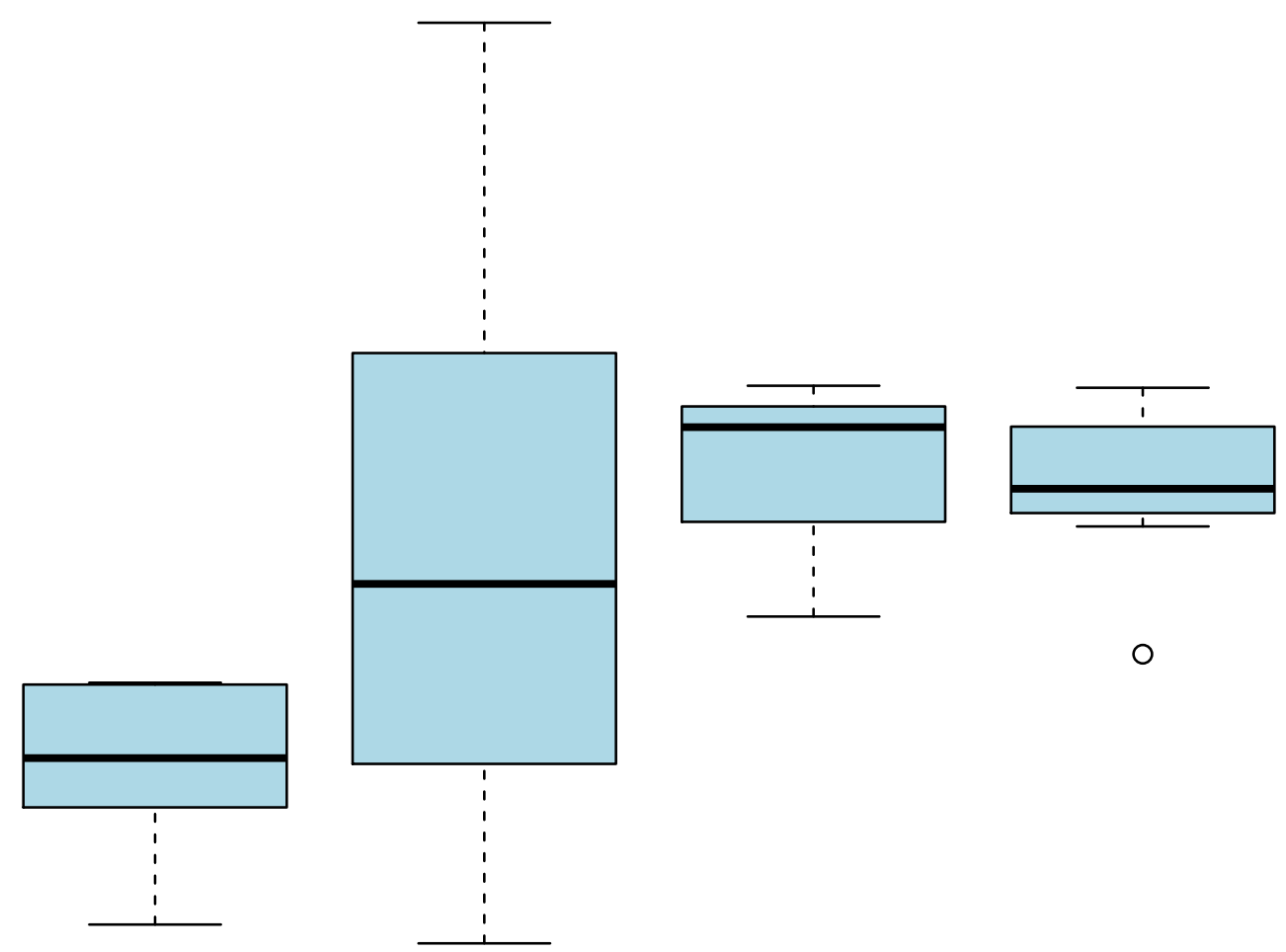

O

Freshwater

Coastal

Shelf

Deep

Habitat 


\section{Table $\mathbf{1}$ (on next page)}

Eye types and nebenaugen by family

[p] Table 2: The distribution of nebeaugen and eye types amongst caridean families. Eyes are split into 6 types as described in Table 1 and Figure 1. The binomial test results indicate whether the distribution of nebenaugen deviates significantly from 50:50 by group or eye type. $\mathrm{NE}=$ nebenauge. $[p]$ 


\begin{tabular}{|c|c|c|c|c|c|c|c|c|c|c|c|c|c|c|c|}
\hline \multirow[t]{2}{*}{ Family } & \multicolumn{2}{|c|}{1 - straight } & \multicolumn{2}{|c|}{$2-$ sinuous } & \multicolumn{2}{|c|}{ 3- forward } & \multicolumn{2}{|c|}{4 - large } & \multicolumn{2}{|c|}{ 5, w-shape } & \multicolumn{2}{|c|}{6 , other } & \multicolumn{2}{|c|}{ All } & \multirow[t]{2}{*}{ Binomial test } \\
\hline & $\mathrm{NE}$ & $\begin{array}{l}\text { No } \\
\text { NE }\end{array}$ & NE & $\begin{array}{l}\text { No } \\
\text { NE }\end{array}$ & $\mathrm{NE}$ & $\begin{array}{l}\text { No } \\
\text { NE }\end{array}$ & $\mathrm{NE}$ & $\begin{array}{l}\text { No } \\
\text { NE }\end{array}$ & $\mathrm{NE}$ & $\begin{array}{l}\text { No } \\
\text { NE }\end{array}$ & $\mathrm{NE}$ & $\begin{array}{l}\text { No } \\
\text { NE }\end{array}$ & $\mathrm{NE}$ & $\begin{array}{l}\text { No } \\
\text { NE }\end{array}$ & \\
\hline Alpheidae & & 2 & & & & & & & & & & 34 & & 36 & $P<0.0001$ \\
\hline Anchistioidae & 1 & & & & & & & & & & & & 1 & & \\
\hline Atyidae & & 7 & 1 & 6 & & 1 & & 1 & & & & & 1 & 15 & $\mathrm{P}<0.001$ \\
\hline Barbouridae & & & & 1 & & & & & & & & & & 1 & \\
\hline Campylonotidae & & & & & & & & & & 1 & & & & 1 & \\
\hline Crangonidae & & 1 & & 3 & & 1 & & 2 & & 8 & & 3 & & 18 & $P<0.0001$ \\
\hline Desmocarididae & & & & & & & & & & 1 & & & & 1 & \\
\hline Disciadidae & & 1 & & 1 & & 1 & & 1 & & & & & & 4 & \\
\hline Eugonatonotidae & & & & & & & 1 & & & & & & 1 & & \\
\hline Euryrynchidae & & & & & & & & & & & & 1 & & 1 & \\
\hline $\begin{array}{l}\text { Glyphocrangonid } \\
\text { ae }\end{array}$ & & & & & & & & 1 & & & & & & 1 & \\
\hline Gnathophyllidae & 1 & 1 & & & & 1 & & & & 1 & & 1 & 1 & 4 & \\
\hline Hippolytidae & 2 & 9 & 10 & 6 & & 3 & & 1 & & 1 & & 2 & 12 & 22 & n.s. \\
\hline Hymenoceridae & 1 & & 1 & & & & & & & & & & 2 & & \\
\hline $\begin{array}{l}\text { Nematocarcinida } \\
\text { e }\end{array}$ & & & & 3 & & 1 & & & & & & & & 4 & \\
\hline Ogyrididae & & 1 & & & & & & & & & & & & 1 & \\
\hline Oplophoridae & 1 & & 3 & 1 & 2 & 2 & & & & & & 1 & 6 & 3 & n.s. \\
\hline Palaemoninae & & & 14 & 1 & & 1 & & & & 1 & & 1 & 14 & 4 & $\mathrm{P}<0.05$ \\
\hline Pandalidae & 1 & 6 & 6 & 4 & & & 5 & 2 & & & & & 12 & 12 & n.s. \\
\hline Pasiphaeidae & & 3 & & & & 1 & & & & 2 & & 1 & & 7 & $P<0.05$ \\
\hline Pontoniinae & 23 & 59 & 6 & 6 & 4 & 5 & & 2 & & 5 & & 1 & 33 & 78 & $P<0.0001$ \\
\hline Processidae & & & & & & & & & 1 & 4 & & & 1 & 4 & \\
\hline Rhinchocinetidae & & & 2 & & & & & & & & & & 2 & & \\
\hline Stylodactylidae & & & & 1 & & 1 & & & & & & & & 2 & \\
\hline $\begin{array}{l}\text { Thalassocaridida } \\
\text { e }\end{array}$ & & & & & & & 1 & & & & & & 1 & & \\
\hline Xiphocarididae & & & 1 & & & & & & & & & & 1 & & \\
\hline Total & 30 & 90 & 44 & 33 & 6 & 18 & 7 & 10 & 1 & 24 & 0 & 50 & 84 & 224 & $P<0.0001$ \\
\hline Binomial test & $\mathrm{P}<$ & 001 & & & & & & & & 001 & & 001 & & & \\
\hline
\end{tabular}

2 NB Acanthephyridae and Oplophoridae have recently been recognised as being monophyletic and are so presented here as Oplophoridae (Wong et al 2015) 